\title{
Klasifikasi Penyakit Kulit Wajah Menggunakan Metode Convolutional Neural Network
}

\author{
Classification of Facial Skin Diseases Using the Method of the \\ Convolutional Neural Network
}

\author{
Nurkhasanah ${ }^{1}$, Murinto ${ }^{2 *}$ \\ ${ }^{1,2}$ Program Studi Teknik Informatika Univarsitas Ahmad Dahlan Yogayakarta \\ *corr-author: murintokusno@tif.uad.ac.id
}

\begin{abstract}
ABSTRAK
Permasalahan kulit tidak hanya merugikan kesehatan fisik namun dapat juga menimbulkan masalah psikologi, terutama jika penyakit kulit ini terjadi di wajah. Pemeriksaan yang dilakukan oleh dokter saat ini hanya mengandalkan penglihatan objek mata dan riwayat penyakit pasien, sehingga memungkinkan terjadinya kesalahan pada analisis dan diagnosa penyakit. Penelitian ini dilakukan untuk menghasilkan sistem klasifikasi penyakit kulit wajah menggunakan metode convolutional neural network $(\mathrm{CNN})$. Data yang digunakan pada penelitian ini sebanyak 500 sampel data citra dengan 5 Jenis penyakit kulit wajah yaitu jerawat, eksim, milia, herpes, dan melasma. Pada penelitian ini proses klasifikasi menggunakan metode CNN. Arsitektur model yang digunakan adalah VGG16. Dalam pemodelan VGG16 terdapat dua lapisan yaitu feature extraction dan classification. Di dalam feature extraction terdapat convolution layer menggunakan 3 layer dengan kedalaman filter yang berbeda pada setiap layernya. Fungsi aktivasi ReLu dan avarage pooling digunakan untuk mengurangi feature map. Lapisan classification terdapat fully connected layer dan softmax digunakan untuk klasifikasi. Metode CNN yang digunakan pada penelitian ini memperoleh hasil yang sangat baik, dimana didapat hasil proses pelatihan sebesar $98 \%$ dan hasil validasi $88 \%$ dengan data pealtihan sebanyak 325 citra dan data validasi sebanyak 125 . Hasil akurasi yang didapat pada pengujian terhadap data baru sebesar 90\% dengan data uji sebanyak 50 citra. Dengan demikian, dapat dikatakan hasil yang diperoleh pada pengujian penelitian ini sangat baik.
\end{abstract}

Kata-kata kunci: CNN, klasifikasi, penyakit kulit wajah, VGG16.

\begin{abstract}
The skin problems are not only detrimental to physical health but can also cause psychological problems, especially if this skin disease occurs on the face. Examinations carried out by doctors currently only rely on eye object vision and the patient's disease history, thus allowing errors in the analysis and diagnosis of disease. This research was conducted to produce a classification system for facial skin diseases using the convolutional neural network (CNN) method. The data used in this study were 500 samples of image data with 5 types of facial skin diseases, namely acne, eczema, milia, herpes, and melasma. In this study, the classification process uses the CNN method. The model architecture used is VGG16. In VGG16 modeling there are two layers, namely feature extraction and classification. In the feature extraction there is a convolution layer using 3 layers with different filter depths in each layer. ReLu activation function and average pooling are used to reduce the feature map. The classification layer is a fully connected
\end{abstract}


layer and softmax is used for classification. The CNN method used in this study obtained very good results, where the results of the training process were $98 \%$ and the validation results were $88 \%$ with 325 training data images and 125 validation data. The accuracy results obtained in testing the new data were $90 \%$ with test data of 50 images. Thus, it can be said that the results obtained in this research test are very good.

Keywords: CNN, classification, facial skin disease, VGG16.

\section{PENDAHULUAN}

Kesehatan merupakan aspek penting dalam kehidupan, salah satu cara yang dapat dilakukan agar dapat hidup sehat dan terhindar dari penyakit yaitu dengan menjaga pola hidup sehat. Gangguan kesehatan kerap mengganggu pada manusia, salah satu jenis penyakit yang banyak dialami oleh manusia ialah penyakit kulit. Kulit merupakan organ terbesar bagi tubuh manusia, dimana kulit ini berfungsi sebagai pelindung bagi organ dalam. Menjaga kesehatan kulit sangatlah penting karena kulit memiliki sifat yang sensitif, terutama pada kulit bagian wajah karena kulit wajah merupakan bagian kulit yang sering terpapar cahaya matahari dan udara secara langsung. Sehingga dapat lebih rentan terkena gangguan penyakit kulit dibandingkan bagian kulit lainnya. Wajah merupakan bagian tubuh yang sangat diperhatikan baik wanita maupun pria, memiliki wajah yang sehat dan bersih tentu menjadi impian bagi setiap orang, namun tidak sedikit pula orang yang memiliki gangguan pada kulit wajahnya. Hal ini tentu akan sangat menggangu, tidak hanya pada penampilan namun, kepercayaan diripun sedikit demi sedikit akan hilang bahkan dapat mengganggu pada mental penderita gangguan penyakit kulit.Kurangnya pengetahuan tentang penyakit kulit dan cara penanganan dengan benar akan mengakibatkan terjangkit penyakit kulit akut. Selain itu, Saat ini pemeriksaan yang dilakukan oleh dokter kulit hanya mengandalkan visual objek mata serta riwayat penyakit pasien, sehingga dapat memungkinkan terjadinya kesalahan dalam analisi dan diagnosa penyakit.

Beberapa metode yang digunakan sebelumnya untuk mendiagnosa penyakit kulit wajah di antara dilakukan oleh Aziz dan Karpen (2019), di mana dalam penelitiannya metode yang digunakan adalah decision tree dan algoritma $C 4$. Dalam penelitian ini decision tree digunakan untuk menemukan hubungan antara calon sejumlah veriabel sehingga dijadikan sebgaia variabel target dalam bentuk pohon. Hasil klasifikasi dimasukkan ke dalam algoritma C4.5. Sedangkan penelitian yang dilakukan oleh Yasir $\operatorname{dkk}(2015)$ menggunakan artificial neural network (ANN) untuk mendeteksi penyakit kulit, di mana berbagai jenis pemrosesan citra untuk ekstraksi fitur dan feed forward ANN untuk pelatihan dan pengujian model dalam penelitian ini. Sistem yang dibangun berhasil mendeteksi 9 jenis penyakit kulit yang berbeda dengan rata-rata akurasi $90 \%$.

Semenjak artificial neural networks (ANN) menunjukkan suatu kinerja yang baik khususnya convolutional neural networks (CNN) (Kadam dkk, 2020; Fernandes Junior and Yen, 2019; Ahmed and Darwish, 2021), maka pekerjaan ini difokuskan pada identifikasi jaringan terbaik. Identifikasi dan klasifikasi jenis penyakit kulit wajah dapat menggunakan pendekatan machine learning. Studi yang dilakukan oleh Wu et al. (2019) mempelajari algoritma CNN yang berbeda-beda untuk klasifikasi penyakit kulit didasarkan pada citra secara klinis. Hasil penelitian menunjukkan akurasi $92.9 \%$ untuk penyakit kulit lupus erythematosus (LE), 89.2\% untuk penyakit kulit basal cell carcinoma (BCC), dan $84.3 \%$ untuk seborrheic keratosis (SK). Penelitian lain yang dilakukan oleh Suartika dkk (2016)berhasil membangun sistem klasifikasi citra pada Caltech 101, dilakukan untuk mengetahui apakah metode CNN dapat melakukan klasifikasi dengan baik pada data base Caltech 101 dengan tingkat confiusion yang berbeda-beda. Berdasarkan pengujian pada 
penelitiannya mendapatkan hasil akurasi yang cukup baik. Pada penelitian yang dilakukan oleh Savera dkk (2020) mengenai deteksi dini kanker kulit. Hasil yang didapat dari dua metoda yang digunakan yaitu dengan $\mathrm{CNN}$ dan KNN masih dapat ditingkatkan pada penelitian lanjutan, yaitu dengan melakukan prapengolahan pada set data citra yang digunakan. Proses ini dilakukan agar memiliki tingkat pencahayaan, sudut (pengambilan), serta ukuran citra yang sama pada dataset yang digunakan. Apabila memungkinkan dapat menambahkan jumlah citra yang digunakan, baik itu sebagai set data latih maupun uji.

Model arsitektur CNN yang ada antara lain Arsitektur VGG16 (Simonyan and Zisserman, 2015) yang merupakan salah satu bagian dari arsitektur CNN digunakan pada penelitian ini. Penelitian lain yang menggunakan VGGnet antara lain dilakukan oleh Penelitian yang dilakukan bertujuan untuk mempermudah dalam mengetahui jenis penyakit kulit pada wajah berdasarkan citra. Diharapkan dengan sistem pengenalan citra penyakit kulit pada wajah ini dapat membantu dokter dan pasien dalam menganalisis kondisi wajah sehingga dapat melakukan perawatan dan pemilihan produk perawatan wajah sesuai dengan kebutuhannya.

\section{METODE PENELITIAN}

Data citra penyakit kulit wajah dikumpulkan dan dijadikan dataset yang digunakan untuk penelitian ini. Objek yang digunakan ialah citra penyakit kulit wajah yang terdiri dari 5 jenis yaitu jerawat, milia, melasma, Eksim dan Herpes. Penelitian ini diharapakan dapat memberikan hasil yang terbaik, sehingga mampu membantu tenaga medis untuk mengetahui jenis penyakit kulit wajah yang sedang dialami. Perangkat lunak yang digunakan adalah: Windows 10 professional, Google Colab, Python 3.7, Library keras, Tensorflow dan Anaconda 364 Bit. Pada penelitian ini, peneliti menggunakan data yang telah disediakan oleh pihak-pihak lain yang digunakan untuk penelitian. Data sekunder yang digunakan didapat dari halaman dataset kaggle (https://www.kaggle.com/datasets). Dalam Gambar 1 diperlihatkan diagram alir penelitian yang dilakukan untuk klasifikasi penyakit kulit wajah berdasarkan citra wajah menggunakan CNN.

Pemodelan CNN yang dibangun pada penelitian ini digunakan pada proses pengolahan data. Model yang dibangun bertujuan untuk memastikan jumlah layer yang akan dipakai, memastikan ukuran kernel. Memastikan filter, memastikan fungsi aktifasi dan memastikan ukuran Avarage Pooling. Arsitektur CNN yang digunakan pada penelitian ini berdasarkan pada arsitektur VGG16, seperti yang terlihat dalam Gambar 2. Di dalam arsitektur VGG16 terdapat 2 lapisan yaitu feature extraction dan classification. Pada lapisan feature extraction meggunakan sebanyak 3 layer convolution dan dengan jumlah filter yang berbeda pada setiap layernya. Selain itu, aktivasi relu dan avarage pooling juga digunakan untuk mengurangi feature map pada citra. Kemudian hasil dari feature extraction ini akan diproses oleh fully connected layer berdasarkan kelasnya dengan menggunakan aktivasi softmax. ukuran kernelnya yang digunakan berukuran (3x3) dengan satu langkah pergeseran filter. Pada proses Avarage pooling menggunakan ukuran $(2 \times 2)$ dengan satu langkah pergeseran filter. Avarage pooling digunakan untuk menghitung ratarata dari matriks pada operasi pooling untuk mendapatkan output pada konvolusi terakhir dengan demikian didapat keluaran model menjadi tensor 2D. Pada Fully Connected Layer yaitu sebagai final clasification. Dimana Pada fully connected layer semua node terkoneksi dengan layer sebelumnya. Layer ini memiliki hidden layer, activation function, output layer dan loss function. Dimana setiap layernya memiliki neuron-neuron yang saling terhubung dengan neuron-neuron pada layer tetangga. Neuron-neuron ini akan ditransformasikan terlebih dahulu menjadi satu dimensi sebelum dimasukkan kedalam fully connected layer untuk mempertahankan karaktek spasial dari data. Selain itu, hasil pooling yang akan digunakan sebagai inputan, terlebih dahulu diubah menjadi sebuah vektor untuk digunakan 
sebagai inputan fully connected layer. Kemudian kelas citra dikelompokkan sesuai nilai neuron pada hidden layers dengan menggunakan fungsi aktivasi softmax. Output layers berisi probabilitas dari setiap kelas yang diprediksi oleh classifier.

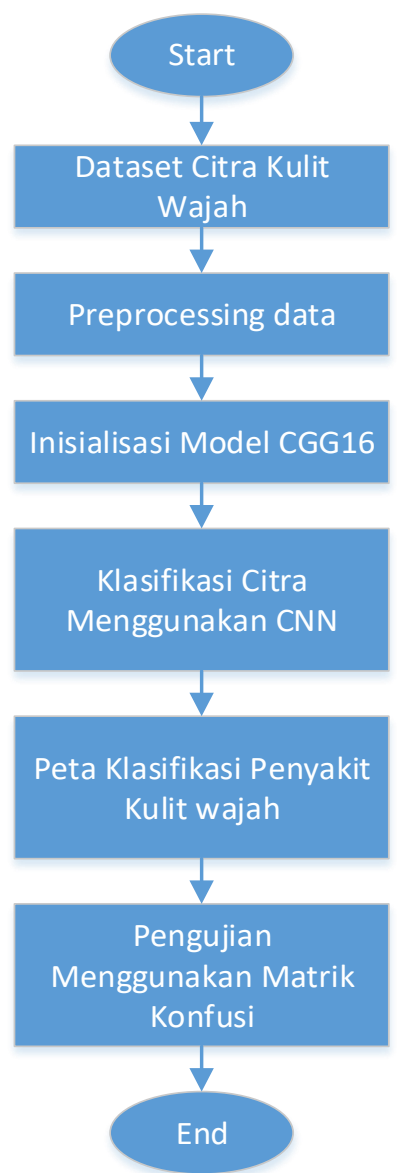

Gambar 1. Diagram alir klasifikasi penyakit kulit wajah menggunakan CNN

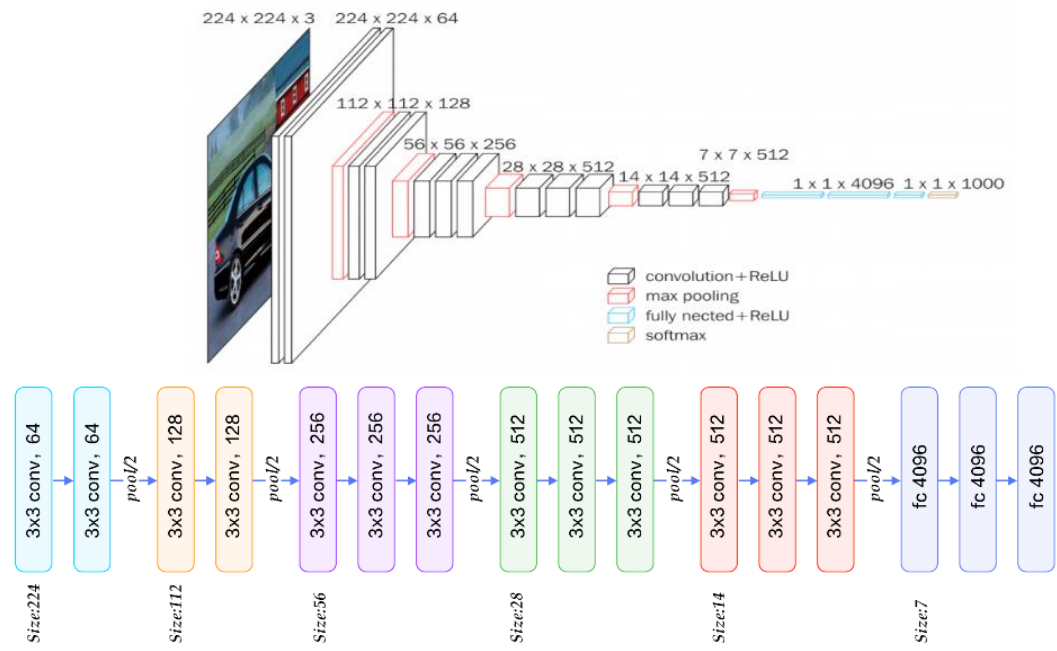

Gambar 2. Arsitektur VGG16 (Simonyan and Zisserman, 2015) 


\section{HASIL DAN PEMBAHASAN}

\section{Dataset Penelitian}

Data yang digunakan pada penelitian ini merupakan data citra penyakit kulit wajah yaitu Jerawat, herpes, Milia, Melasma, dan eksim. Total data yang digunakan sebanyak 500 data citra penyakit kulit wajah, dimana data tersebut kemudian dibagi menjadi data pelatihan sebanyak 325 citra, data validasi sebanyak 125 citra, dan data pengujian sebanyak 50 citra. Prepocessing data dalam penelitian ini digunakan untuk mengelompokkan setiap data inputan citra kedalam kelas citra berdasarkan jenis penyakit kulit. Adapun dataset yang digunakan sebanyak 500 citra yang dibagi kedalam 5 kelas penyakit kulit wajah. Dataset yang digunakan terdiri dari data pelatihan sebanyak 325 dengan masing-masing kelas memiliki 63 data citra, sedangkan data validasi sebanyak 125 citra dimana setiap kelasnya memiliki 25 citra, dan sebanyak 50 citra digunakan sebagai data pengujian atau data baru yang dibagi kedalam 5 kelas dengan masing-masing kelas mempunyai 10 citra baru. Dalam Gambar 3 diperlihatkan contoh jenis penyakit kulit wajah yang diambil dari Kaggle dataset.

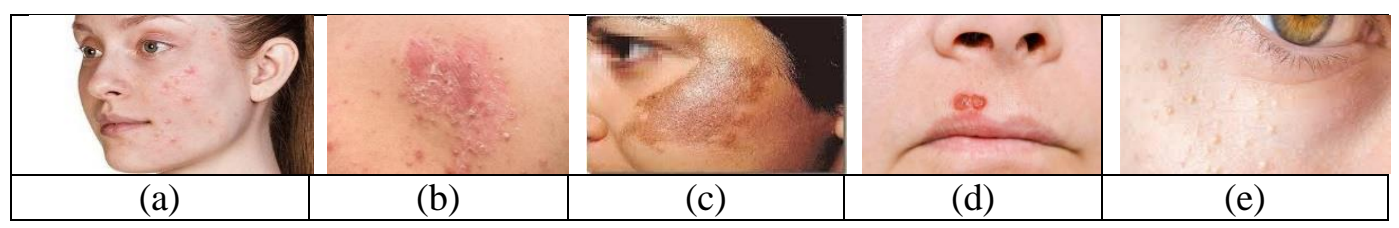

\section{Gambar 3. Jenis penyakit kulit wajah (a) Jerawat (b) Eksim (c ) Melasma (d) Herpes (e) Milia (kaggle.com)}

Tahapan prepocessing data dilakukan dengan cara augmentasi yaitu dengan membalikkan gambar secara vertikal dan horizontal. Proses augmentasi digunakan pada proses klasifikasi data pelatihan dan data validasi. Augmentasi dilakukan untuk menghasilkan batch data gambar tensor dengan augmentasi data real. Augmentasi dapat memperbanyak dataset $10 \mathrm{kali}$ dari satu data original, sehingga dapat meminimalisir terjadinya overvitting. Proses augmentasi ini dilakukan pada pemrosesan data pada python. Pada penelitian ini pengujian model dilakukan pada data training, validasi dan data testing. untuk mengetahui hasil akurasi yang didapat, sebelumnya peneliti juga menentukan hyperparameter yang akan digunakan pada pelatihan model yang digunakan pada data training dan data validasi saja dengan menggunakan pemodelan CNN yaitu VGG16. Sedangkan pengujian pada data testing dilakukan dengan menggunakan confution matriks. Optimizer yang digunakan adalah Adam dengan learning rate sebesar 0.0001 dan epoch sebesar 100.

\section{Pelatihan dan Validasi}

Pada penelitian ini dilakukan proses pelatihan dan validasi data pada citra training sebanyak 320 dan sebanyak 125 citra validation dengan format *.jpg. Pada training terdapat 5 kelas, dimana setiap kelasnya terdapat 64 citra penyakit kulit wajah. Sedangkan pada data validation berjumlah 125 citra peyakit kulit dimana setiap kelasnya terdapat 25 citra penyakit kulit. Berikut hasil dari pengujian kedua data tersebut dapat dilihat pada Gambar 4. 


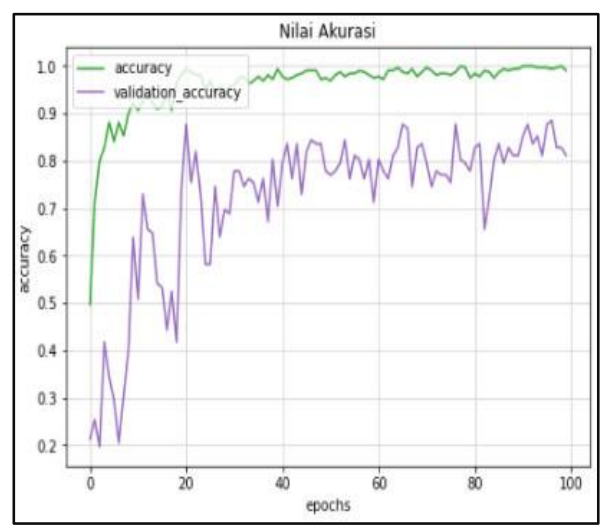

(a)

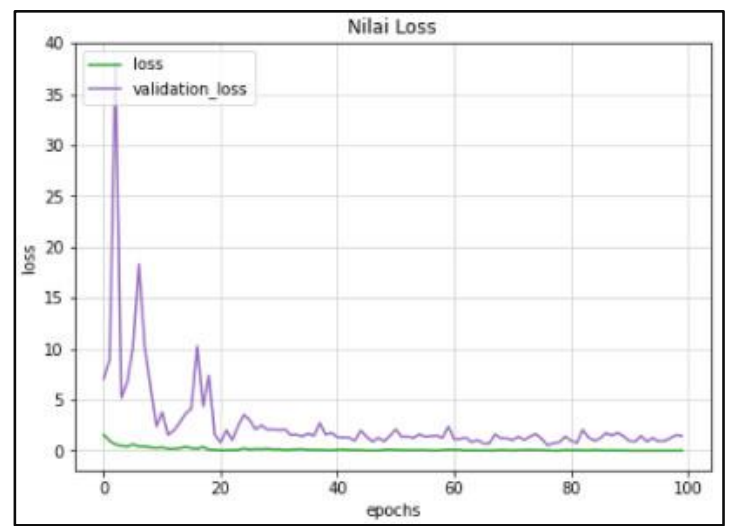

(b)

Gambar 4. Grafik accuracy (a) dan loss (b) model CNN

Pengujian yang dilakukan pada data training dan validation mendapatkan hasil accurasy sebesar $100 \%$ dan hasil validation mendapatkan hasil $88 \%$. Selain itu, pengujian model dengan menggunakan arsitektur $\mathrm{CNN}$ yang lain juga dilakukan untuk membandingkan dan mengetahui hasil arsitektur terbaik yang didapat. Hasil yang didapat pada perbandingan arsitektur yang digunakan terlihat dalam Tabel 1.

Tabel 1. Hasil akurasi menggunakan arsitektur yang lain

\begin{tabular}{ccccc}
\hline \multirow{2}{*}{ No. } & \multirow{2}{*}{ Model } & \multirow{2}{*}{ Epoch } & \multicolumn{2}{c}{ Akurasi } \\
\cline { 4 - 5 } & & 500 & Akurasi & Matrik Konfusi \\
\hline 1 & MobileNetV2 & 1000 & $80 \%$ & $12 \%$ \\
2 & ResNet50 & 100 & $88 \%$ & $64 \%$ \\
3 & VGG16 & $100 \%$ \\
\hline
\end{tabular}

Berdasarkan Tabel 1 hasil akurasi yang didapat dengan menggunakan arsitektur MobileNetV2, ResNet50 dan VGG16 nilai akurasi terbaik yaitu dengan menggunakan VGG16, yaitu sebesar $88 \%$ dan pada pengujian dengan matrik konfusi sebesar $90 \%$. Sedangkan pengujian dengan menggunakan MobileNetV2 dan ResNet50 hasil yang didapat tidak baik dan terjadi overfitting. Selain itu, epoch yang digunakan pada kedua arsitektur tersebut juga sangat banyak sehingga membutuhkan waktu yang cukup lama pada proses training. Oleh karena itu arsitektur MobileNetV2 dan ResNet50 ini tidak digunakan pada penelitian ini karena hasil akurasi yang tidak bagus dan membutuhkan waktu yang cukup lama pada saat proses training sehingga dirasa kurang efektif.

\section{Data Pengujian}

Pengujian yang dilakukan pada data pengujian menggunakan data baru atau data yang sebelumnya tidak terdapat pada data pelatihan dan validasi. Data yang digunakan pada data pengujian sebanyak 50 data dengan masing-masing kelasnya berjumlah 10 data citra. Data pengujian yang digunakan untuk pengujian validitas atas hasil akurasi yang didapat pada data pelatihan dan pengujian. Pengujian ini dilakukan dengan menggunakan metode matrik konfusi . Dalam Tabel 2 diperlihatkan hasil yang didapat pada pengujian data pengujian. 
Tabel 2. Hasil matrik konfusi pada data pengujian

\begin{tabular}{lcccccc}
\hline \multirow{2}{*}{ Kelas } & \multicolumn{6}{c}{ Prediksi } \\
\cline { 2 - 7 } & Eksim & Herpes & Jerawat & Melasana & Milia & Total \\
\hline Eksim & 10 & 0 & 0 & 0 & 0 & 10 \\
Herpes & 1 & 8 & 0 & 0 & 1 & 10 \\
Jerawat & 2 & 0 & 7 & 1 & 0 & 10 \\
Melasna & 0 & 0 & 0 & 10 & 0 & 10 \\
Milia & 0 & 0 & 0 & 0 & 10 & 10 \\
\hline
\end{tabular}

Tabel 2. merupakan hasil pengujian pada data pengujian, hasil yang didapat sangat baik. Pemberian warna hijau pada kolom yang terdapat angka menunjukkan keberhasilan pada klasifikasi data baru, sedangkan warna merah yang terdapat pada kolom merupakan kesalahan dalam prediksi klasifikasi penyakit kulit. Hasil data yang berhasil diklasifikasi secara benar sebanyak 45 data dari 50 data. Dan sebanyak 5 data yang diklasifikasi secara salah yaitu pada penyakit herpes terdapat 2 kesalahan klasifikasi, kemudian pada jerawat sebanyak 3 data yang diklasifikasi dengan salah. Adapun kesalahan dalam klasifikasi citra dapat terjadi karena kualitas gambar yang digunakan, dimana pada data terdapat beberapa gambar yang blur dan kurang jelas, sehingga dapat mempengaruhi hasil klasifikasi yang dilakukan. Perhitungan akurasi pada pengujian yang terdapat pada Tabel 3 ialah sebagai berikut :

$$
\begin{aligned}
\text { overall accuracy }(O A)= & \frac{j \text { umlah citra yang diprediksi benar }}{\text { jumlah data }} \\
& =\frac{45}{50}=90 \%
\end{aligned}
$$

Akurasi yang didapat dari model CNN dengan citra input berukuran $128 \times 128$ piksel, dengan menggunakan sebanyak 50 citra data baru. Pengujian model menghasilkan nilai akurasi sebesar $90 \%$, nilai tersebut didapat dari pembagian jumlah data citra yang diprediksi secara benar dengan total data citra keseluruhan. Dengan ini, hasil implementasi model CNN yang telah dibuat mendapatkan hasil yang baik untuk mengklasifikasi jenis penyakit kulit wajah.

\section{KESIMPULAN}

Berdasarkan hasil penelitian yang dilakukan, maka didapat beberapa kesimpulan yaitu Penelitian yang telah dilakukan menghasulkan sebuah sistem klasifikasi penyakit kulit wajah menggunakan metode convolutional neural network (CNN). Tingkat akurasi yang didapatkan pada proses pelatihan sebesar $100 \%$ sedangkan pada proses pengujian sebesar $88 \%$ dan pada pengujian data baru sebesar $90 \%$. Dengan begitu, dapat disimpulkan bahwa penerapan deep learning dengan memakai metode convolutional neural network dapat melakukan klasifikasi penyakit kulit wajah dengan sangat baik. Diharapkan pada penelitian selanjutnya dapat memperbanyak dataset citra dan kelas terhadap data pelatihan maupun data pengujian dengan harapan dapat meningkatkan hasil akurasi yang lebih maksimal. Akurasi dapat ditingkatkan juga dengan menerapkan $\mathrm{CNN}$ dan transfer learning.

\section{DAFTAR PUSTAKA}

Ahmed, A. A. and Darwish, S. M. (2021) 'A Meta-Heuristic Automatic CNN Architecture Design Approach Based on Ensemble Learning', IEEE Access, 9, pp. 16975-16987. Ayumi, V. et al. (2017) 'Optimization of convolutional neural network using 
microcanonical annealing algorithm', 2016 International Conference on Advanced Computer Science and Information Systems, ICACSIS 2016, pp. 506-511. d

Aziz, A. and Karpen (2019) 'Diagnosa Penyakit Kulit Wajah Menggunakan', Jurnal Teknologi Dan Open Source, 2(1), pp. 74-86.

Fernandes Junior, F. E. and Yen, G. G. (2019) 'Particle swarm optimization of deep neural networks architectures for image classification', Swarm and Evolutionary Computation. Elsevier B.V., 49(June), pp. 62-74. doi: 10.1016/j.swevo.2019.05.010.

Kadam, S. S., Adamuthe, A. C. and Patil, A. B. (2020) 'CNN Model for Image Classification on MNIST and Fashion-MNIST Dataset', Journal of scientific research, 64(02), pp. 374-384.

Savera, T. R., Suryawan, W. H. and Setiawan, A. W. (2020) 'Deteksi Dini Kanker Kulit Menggunakan K-Nn Dan Early Detection of Skin Cancer Using K-Nn and Convolutional', Jurnal Teknologi Informasi Dan Ilmu Komputer, 7(2), pp. 373-378.

Simonyan, K. and Zisserman, A. (2015) 'Very deep convolutional networks for large-scale image recognition', 3rd International Conference on Learning Representations, ICLR 2015 - Conference Track Proceedings, pp. 1-14.

Suartika E. P, I Wayan, Wijaya Arya Yudhi, S. R. (2016) 'Klasifikasi Citra Menggunakan Convolutional Neural Network (Cnn) Pada Caltech 101', Jurnal Teknik ITS, 5(1), p. 76. Available at: http://repository.its.ac.id/48842/.

Wu, Z. et al. (2019) 'Studies on Different CNN Algorithms for Face Skin Disease Classification Based on Clinical Images', IEEE Access, 7(c), pp. 66505-66511.

Yasir, R., Rahman, M. A. and Ahmed, N. (2015) 'Dermatological disease detection using image processing and artificial neural network', 8th International Conference on Electrical and Computer Engineering: Advancing Technology for a Better Tomorrow, ICECE 2014, pp. 687-690. 